\title{
Virtual Environment Based on Integrating Active Learning Google Applications to Develop Using Moodle Skills
}

\author{
Hamzah Mahmoud Daradkah (Corresponding author) \\ Ministry of Education - Kingdom of Bahrain \\ Bahrain - West Rifaa - Street Sh, Mohamad Avenue -Road 1019 - Block910 - Building 587- \\ School Serial No:1408 \\ E-mail: daradkahhamzah@gmail.com Tel: 0097336446780
}

Received: May 2, 2018

doi:10.5296/jet.v5i2.13086
Accepted: May 28, 2018

Published: August 14, 2018

URL: http://dx.doi.org/10.5296/jet.v5i2.13086

\begin{abstract}
The aim of this research is to identify the effect of designing a virtual environment based on the integration of active learning and Interactive Google applications in developing the skills of using the e-Learning Management System (e-LMS) Moodle among the students of the Faculty of Education at Mu'tah University in Jordan. The research sample consisted of (30) students randomly selected from the Faculty of Education at Mu'tah University in Jordan. The research tools included an achievement test to measure the cognitive aspects of the skills of using the (e-LMS) Moodle and a note card to measure the performance aspects of the skills of using the (e-LMS) Moodle. The study revealed a statistically significant difference between the average scores of the experimental group in the pre and post- test of the(e-LMS) Moodle for students of the Faculty of Education for post-test, as well as the existence of a statistically significant difference between the average scores of the experimental group in the pre- and post-test of the observation card related to the skills used or the (e-LMS) Moodle for students of the Faculty of Education for the benefit of post-test.The study had several recommendations, the most important of which is the need to work on the employment of Google Interactive Applications and e-learning strategy in the participatory virtual environments, and work on the development of the skills of using e-LMSs among the different groups of the administrators of the educational process.
\end{abstract}

Keywords: Virtual Environment, Google Applications, Active Learning, e-Learning Management System

\section{Introduction}

The development of information and communication technology (ICT), the emergence of web networks and changing their tools from one generation to the next, and the multiplicity of services and applications offered by Google in the educational process have led to the 
emergence of new styles and methods of learning based on learner activity and effectiveness. These styles and methods provide a great deal of Interactive for the learner in the learning process time and place that are appropriate for him. This requires the creation of an appropriate educational environment that seeks to exploit the modern capabilities of multimedia technology in the design of virtual environments, in order to improve the future variables of the education system and draw a clear picture for them in order to participate in the graduation of qualified human cadres capable of keeping up with these developments.

Britian (2004) suggests that the virtual environment provides an Interactive learning environment that attracts the learner, and makes him/her deal with things in a natural way. It also provides the learner with audio and/or text guidance that facilitates integration into the environment. This virtual environment provides an educational opportunity for learners to refine and strengthen their abilities, and help them to learn and develop the skills required. Rossiou, Paparrizos, \& Papadakis(2009) points to the effectiveness of virtual environments, which is demonstrated by improving and enhancing learner experience, improving learning outcomes, attaining cognitive goals, acquiring knowledge and expression in a variety of ways for all learners, and positive acceptance by teachers and learners towards the virtual environment.

Holmes et al (2015) state that Google's Interactive applications have enhanced the learner's involvement within the learning process, which promotes active learning. It gives the learners a real opportunity to practice the actual application of learned knowledge, and allows the learners to interact with teachers and peers through the use of Google Apps in the learning process that supports and promotes active learning, providing an Interactivelearning environment that suits many types of student learning and takes into account the individual differences between them.

The Interactive Google applications have a variety of features and characteristics that distinguish them from other applications. These features are represented by their ability to organize and manage content over the Internet, and enable them to send and receive various activities between students and their teachers at any time and from anywhere. In addition, they provide a safe and free electronic learning environment for both teachers and learners. What's more, they increase the motivation of learners towards learning because they contain a lot of educational elements (Pappas, 2014).

Therefore, the current research sought to take advantage of the characteristics of the features of Google Interactive Applications within the educational process. The research reveals their effectiveness of e-Learning Management System(e-LMS) in developing the skills of students' using these applications especially with the rapid growth in the use of the Internet by the students, and employing the(e-LMS) in educational process as a whole.

Virtual learning environments, which are based on the Electronic Collaborative Learning strategy as an active learning strategy, rely on a set of tools that are used over the Internet to achieve their goals. Without these tools, they cannot play the roles they must play. E-learning Participation tools are different from e-course tools. Each has its own independent features. The Electronic Collaborative Learning environments can include a number of non-participatory e-courses, such as e-mail, news boards, photo albums, web search and visitors record (Lynch, 2002). 
Learning Management System (LMS) systems support and enforce the learning process so that the teacher develops teaching materials from lectures, exams and various resources. They are considered as programs that promote the dissemination of academic courses, the management of student records and follow-up their activities. They also promote the possibility of communication between students and teachers through special forums, and work on the dissemination and evaluation of exams (Khalifa, 2009).

The research is a scientific addition to the field of specialization in terms of developing a list of criteria for the design of a virtual environment based on the integration of active learning and Google Interactive Applications. These criteria can benefit the educational designers. They can also benefit the researchers in the educational technology with the proposed design of a virtual environment through the integration of active learning and Google Interactive Applications to do other studies and apply them in other materials and courses.

Hence, the researcher found the need to design a virtual environment based on the integration of active learning and Interactive Google applications to achieve a high level of indulgence, interaction and exchange of information among learners in order to develop their skills in e-learning management via utilizing the services and applications provided by Google in the educational process. Google Interactive applications promote teamwork and collaboration among learners, whose role is in line with the Electronic Collaborative Learning strategy as an active learning strategy.

\subsection{Literature Review}

Virtual environments are electronic environments that allow simultaneous or asynchronous communication through more efficient tools that are compatible with the nature of the second-generation e-learning, enabling the teacher to disseminate educational content, develop activities and training tasks, and communicate with learners using written texts, audio, images, videos, live conversations, files and their transmission and reception (Parker \& Martin, 2011). Abed El-Aziz (2015) found the effectiveness of an adaptive virtual environment based on participatory media in the development of both knowledge management skills and self-structured e-learning skills among high school students. Similarly, the results of Ahmed's study (2014) indicate the effectiveness of developing virtual learning environments in providing students with instructional design skills for e-courses. In the same vein, Kim's study (2013) confirmed that the use of virtual learning environments leads to far higher educational outcomes, and has a significant impact on students' attitudes towards collaboration and participation, and the general use of the virtual environment.

In addition, The Fourth International Conference on e-learning and Distance Learning, entitled Innovative Education for a Promising Future, in Riyadh, 2-3 March 2015, recommended the use of virtual environments in the learning process for learners at different levels of study.

Wright et al. ( 2012) define Interactive Google Apps as a " group of application that belong to of Google". They include basic services to help deliver work. They also include services that allow businesses and educational institutions to use a variety of Google products, such as e-mail, websites, e-mail, calendar, etc., to communicate and share. 
Al-Darbawi (2017) found the effectiveness of the Interactive Google application databases in developing the ability of the education technology specialist in the skills of publishing educational materials. The study recommended the necessity of employing the Interactive Google applications databases in the educational process. Al-Tony (2016) also pointed to the effectiveness of the use of Google educational applications in developing the skills of knowledge management and self-efficacy among students of educational technology. The study also recommended the use of Interactive Google applications within the educational process.

In a study conducted by Thornton (2016), primary school teachers were trained to integrate teaching strategies and Interactive Google applications into the learning process and to use them to design an online module to disseminate information, electronic documents, and content sharing. These applications have many features, of which they are available to all are free and easy to use. Similarly, Ktoridou \& Nikleia (2013) found that students' perceptions were positive for the use of Google's educational applications in academia and social networking. Tools for them were valuable tools for learning and communication, fulfilling their desires and supporting the learning process.

Holmes et al (2015) conducted a study aimed at identifying the use of Google Interactive Applications in higher education institutions. The study concluded that Google Interactive Applications should be used in the learning process because they are effective in promoting active learning. In the same vein, Cahill (2011) found that faculty members should use Google's Interactive applications and integrate them with different strategies in the learning process, as they are effective in promoting active learning. The study recommended the use of Google Interactive Applications in the educational process.

The Second International Conference on e-learning in the Arab World entitled "Participatory Learning in the Net Society", held at the Egyptian Association of Education Technology from 24-26 June 2014, recommended that all educational and training institutions in the Arab world should take advantage of Google's Interactive applications in the educational process. It also recommends that the faculty of education should take interest in the activation of Interactive Google applications in teaching courses due to their positive impact on students. Furthermore, it encourages teachers to take advantage of Google's Interactive applications in providing the appropriate learning in the technical and virtual environments.

Electronic Collaborative Learning is defined as learning based on the creation of an effective learning environment that provides learners with the opportunity to discuss and engage in knowledge creation and building through interaction with peers and teachers and to make education meaningful to learners (Macro, Ponichet, 2013).

In a study conducted by Hernández, González and Muñoz(2014) entitled "Planning for Electronic Collaborative Learning in Virtual Learning Environments", they design electronic systems supported by Electronic Collaborative Learning, which is one of the most prominent features of technology. The employment of Electronic Collaborative Learning was to be planned in the learning process. The study found that one of the most important features of designing electronic systems supported by Electronic Collaborative Learning is to support 
creativity and innovation, improve the learning process and change it from teacher centered to student centered. The teacher plays the role of facilitator.

A number of studies have been conducted on Electronic Collaborative Learning environments. They recommended the use of Electronic Collaborative Learning to achieve various educational objectives for example, the Ebadi (2014) study emphasized the effectiveness of e-learning environment in the development of digital video editing skills among students of the Education Technology. Ferghali (2011) recommended the need to pay attention to the training of teachers in the use of e-learning participatory teaching. Khalil's (2014) study points to the effectiveness of participatory learning based on Google's educational applications in providing graduate students with the skills to create and manage their cloud computing services.

Sarrab \& Rehman (2014) define LMS as systems that monitor, manage and encourage the interaction between the learner and the teacher, and the learner and the educational content, through which it becomes easy to access to different learning sources and the implementation of tests for different levels of students and to obtain test results in the form of reports.

Several studies and research have pointed to the success of Moodle in significantly enhancing learning and learning strategies, and in designing and developing the best programs for its courses that benefit participants, as confirmed by Nordin, et.al (2012). Similarly, Sarrab \& Rehman (2014), compared three open sources of learning management systems: Atutor, Sakai and Moodle in terms of accessibility, functionality, performance, ease of use, documentation, and financial and commercial support. Moodle surpasses the other two systems. Zhou, Wu, \& Zhan (2014) define Moodle as an event-driven dynamic learning environment and a good learning environment built into the traditional learning and e-learning approach based on the Moodle platform, including content analysis, objectives, activity design, learning assessment, follow-up and sustainability.

There are several studies that have emphasized the importance of e-LMSs and their use within the learning process. The results of Chang et al (2016) study indicate that students' learning has improved markedly using adaptive e-LMS using Moodle \& Mashup. A study conducted by Abu Shuqair, Saeed and Khamis (2012) aimed to develop adaptive performance in the Moodle program at the Islamic University of Gaza. The development included four dimensions: (interface, content, tests, and homework). The results showed that there were statistically significant differences between the average evaluation of Moodle by the students before and after the development of the program in favor of developing the program. Furthermore, Graf (2007) conducted a study aimed at developing adaptive e-learning systems by integrating Moodle learning patterns into learning and identifying patterns of learning from behaviors and activities of learners. The results of the study showed that there was a relationship between learning patterns and the abilities of the students. This relationship should be employed to provide additional information in order to achieve learning patterns. 


\subsection{Statement of the Problem:}

The researcher felt the problem of the study by interviewing some of the students of the Faculty of Education and some faculty members at the University of Mu'tah in Jordan. The students indicated that they were unable to use most of the e-learning management skills despite the importance and urgency of these skills for them to prepare them for their future work. This is confirmed by the faculty members. They emphasized the importance of developing the students' skills to prepare and qualify them for the e-learning era. The researcher also conducted an exploratory study, which consisted of a questionnaire aimed at identifying the training and technological needs in the skills of using the e-learning management system Moodle among the students of the Faculty of Education. The results of the study indicated that $85 \%$ of the students state that they need training on using e-LMS Moodle. The need to develop the requirements of these skills among the students of the Faculty of Education makes it very important to find new methods of education. These methods might include virtual learning environments based on the combination of active learning and Interactive Google applications. They enable collaboration, interaction and cooperation among students in developing the skills of using the e-LMS Moodle.

Hence, the research problem is determined by the lack of performance of the students of the Faculty of Education at the University of Mu'tah in Jordan in using the skills of e-LMS Moodle. These skills have never been studied by students in any of the courses previously taken by students, and the absence of training courses focused on training the students on the skills of using the e-LMS, so students must practice the skills of using e-LMS.

\subsection{Objectives and Questions}

This research aims to:

1) Identify the skills of using the e-LMS Moodle to be taught to the students of the Faculty of Education at the University of Mu'tah, Jordan.

2) Develop a list of virtual environment standards based on the combination of active learning and Interactive Google applications.

3) Designing a virtual environment based on the combination of active learning and Interactive Google applications in accordance with the model of Al-Jazzar (2014).

4) Measuring the impact of designing a virtual environment based on the integration of active learning and Interactive Google applications in developing the cognitive aspects associated with the skills of using e-LMS among students of the Faculty of Education at the University of Mu'tah, Jordan.

5) Measuring the impact of designing a virtual environment based on the integration of active learning and Interactive Google applications in developing the performance aspects associated with the skills of using e-LMS among the students of the Faculty of Education at the University of Mu'tah, Jordan.

To study the goal of the problem, the research requires answering the following main questions:

- How to design a virtual environment based on the combination of active learning and Interactive Google applications? 


\section{Macrothink}

- What effect does this environment have on developing e-learning management skills among students at the Faculty of Education at Mu'tah University in Jordan?

\section{Methodology}

The researcher used the descriptive method to describe the problem, identify its causes, and identify the skills of using the Moodle e-learning system. It was also used to prepare a list of criteria for designing a virtual environment, preparing research tools, and reading previous Arabic and foreign literature and studies. In addition, the researcher used the experimental approach to identify the effect of using the independent variable (designing a virtual environment based on the integration of active learning and Interactive Google applications) on the dependent variables (cognitive and performance aspects associated with the skills of using E-LMS) among the students of the Faculty of Education at the University of Mu'tah, Jordan.

\subsection{Participants}

A random sample of second year students from the Faculty of Education was selected at the University of Mu'tah in Karak Governorate in Jordan. The sample consisted of 30 students during the first semester of the academic year 2017/2018.

\subsection{Research Hypotheses}

1) There is a statistically significant difference at the level of function $(\alpha \geq 0.05)$ between the average scores of the research sample in the pre-test and the post-test of the cognitive test related to the cognitive aspects of the skills of using the e-LMS among the students of the Faculty of Education for the post-application.

2) There is a statistically significant difference at the function level $(\alpha \geq 0.05)$ between the average scores of the research sample members in pre-test and the post-test of the observation card related to the performance aspects of the e-learning management skills of the students of the Faculty of Education for the post-application.

\subsection{Semi-experimental design for research}

The research deals with a single experimental group. In the light of the independent variable, the semi-experimental design of this research is known as "One Group Pretest-Posttest Design". It includes one group which is the experimental group

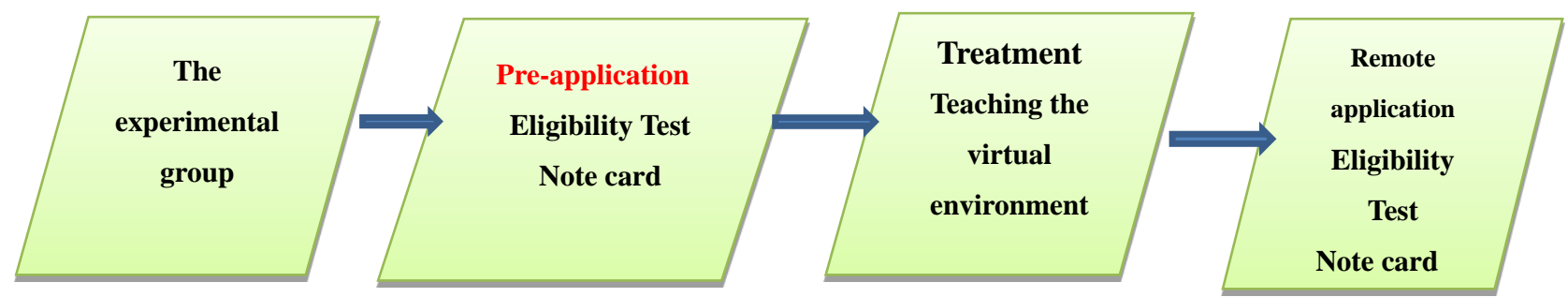

\subsection{Measures}

Search procedures include:

1) Prepare a list of the skills of using the e-LMS, present it to a group of judges and specialists in the field of education technology, and make the necessary adjustments to reach 
the final draft of the skills list. The final list consisted of 46 main skills and 224 secondary skills.

2) Prepare a list of criteria for designing a virtual environment based on the combination of active learning and Interactive Google applications, and adjust them by presenting them to a group of arbitrators and specialists in educational technology and instructional design to reach the final draft of the list. The final list included 13 key criteria and 128 indicators.

3) Prepare the default environment design scenario based on the combination of active learning and Interactive Google applications by introducing it to a group of arbitrators and specialists in the field of educational technology and instructional design, and then modify the scenario according to their views to reach the final draft of the scenario.

4) The current study has limited the use of participatory e-learning as an active learning strategy, as this strategy is in line with Google's Interactive applications and is compatible with virtual environments that emphasize interaction and sharing among learners, and the use of some Interactive Google Application such as; Hangouts, YouTube, Gmail, Google drive, Google+, Google form, and the importance of these applications in the educational process that emphasizes the process of engagement and interaction between teachers and learners, and this with the participatory e-learning strategy.

5) The educational design of the virtual environment according to the Aljazzar Model (2014), which includes the following stages: (Analysis, Design, Construction and Production, Evaluation, and Using).

6) To adjust the search tools by presenting them to a group of arbitrators and specialists in the field of educational technology and educational design, and then modify them according to their opinions and calculate their coefficient of stability.

7) Conduct the exploratory experiment of the research tools and processing of the experiment to identify the application requirements and their suitability for the sample of the research, and identify the problems that the researcher may face during application.

8) Readiness to apply the research: The stage of preparation for the application of the research requires obtaining the approvals of the authorities responsible for the application.

9) Conduct the basic experiment of the research according to the following steps:

- The pre- test of achievement and the observation card are to be used to measure the cognitive and performance aspects of the skills of using the e-LMS among the students of the Faculty of Education at the University of Mu'tah, Jordan. The search tools, namely the achievement test and the observation card, were applied to the research group from 1/11/2017 until 8/11/2017 for approximately one week. They were applied in order to know the level of learners with regard to the dependent skills of the research, namely the cognitive aspect associated with the skills of the use of e-LMS, and the functional aspect associated with these skills before the implementation of the basic experiment of the research.

- The application of processing of the search experience, a virtual environment based on the integration of active learning and Google Interactive Applications to develop the skills of 
using e-LMS among students of the Faculty of Education at the University of Mu'tah, Jordan. In order to conduct the basic research experiment, time and duration of the basic experiment was determined; two months (eight weeks) from Wednesday, 11/11/2017 to Thursday $11 / 1 / 2018$, according to the following steps. First, the researcher interviewed the students of the Faculty of Education (30) students on Wednesday, 11/11/2017 to prepare the members of the research sample for the virtual learning environment through an introductory meeting for an hour. The researcher started the meeting with the sample and introduced them to the virtual learning environment and its objectives and how it will help then in improving their skills in using the e-LMS. Second, the researcher distributed cards with the following information (program link, user name and password) for the virtual environment based on the combination of active learning and Interactive Google applications. It was a researcher's interest to guide the thinking of subjects of the research to the importance of the environment to them and what gains they will make once they have passed the virtual environment. Third, the general objectives of the virtual environment, the training content and the skills involved were also clarified, with some guidance and instructions that facilitated the trainees to navigate the environment. Fourth, the use of the tools of the virtual learning environment was explained with emphasis on programs and versions that must be available on their computers so as not to cause problems during the application and use of the virtual environment. Fifth, the researcher clarified how to use and register and communicate between the sample members with each other, and between the sample members and the researcher. Sixth, the researcher informed the trainees about the road map within the virtual environment and the function of each of them. The researcher also explained to the members of the sample how to answer the achievement pre-test to measure the cognitive aspect of the skills of using the e-LMS.

- Post-application of the achievement test and observation card to measure the cognitive and performance aspects of the skills of using the e-LMS of students of the Faculty of Education at the University of Mu'tah, Jordan. This was done during the period from 12/1/2018 to $16 / 1 / 2018$ in order to identify the extent to which learners achieved skills in using the e-LMS as a result of applying the virtual environment based on the integration of active learning and Google Interactive Applications.

10) Perform appropriate statistical processing for the data reached.

11) To arrive at the results of the research, discuss and interpret them, and make recommendations.

\subsection{Research Tools}

Preparing measurement tools for the dependent variables:

- Achievement test to measure the cognitive aspects of the skills of using the e-LMS among the students of the Faculty of Education at the University of Mu'tah, Jordan. The final test consists of (75) questions divided into two parts: the first part consisted of 38 questions of true and false, while the second part contained 37 questions of multiple-choice. The researcher found that the achievement test has a high degree of stability, where the coefficient of stability according to the equation Kuder-Richardson 20 of the news items (75) questions is (923). This indicates that the test has a high degree of stability (0.35-0.80). The difficulty 
coefficients ranged between $0.20-0.65$, which is acceptable, while the discrimination coefficients of the test vocabulary ranged from 0.36 to 0.50 , which is an acceptable discrimination because it is higher than (0.3).

- Note card to measure the performance aspects of the skills of using the e-LMS by the students of the Faculty of Education at the University of Mu'tah, Jordan. The coefficient of stability is measured by using the Cronbach's alpha( $\alpha)$, which is $(0.94)$, indicating that the observation card has an acceptable degree of stability. This confirms its validity for the application. The coefficient of the correctness of the correctors was also calculated on the note card which equals (90.2\%). This confirms that the observation card has a high degree of stability and is valid as a measurement tool. The rating was used for the observation card. The card included two performance options (skill performed - skill not performed), and the skill level included three levels: high, medium, low). The ratings for the performance levels were distributed as follows:

Table 1. Quantitative assessment of performance levels

\begin{tabular}{|c|c|c|c|}
\hline \multicolumn{3}{|c|}{ Performance level } \\
\hline High & Medium & Low & \\
\hline 3 & 2 & 1 & 0 \\
\hline
\end{tabular}

\section{Findings and Discussion}

The first hypothesis of the research, which states: " There is a statistically significant difference at the level of function $(\alpha \geq 0.05)$ between the average scores of the sample in the pre-test and post-test results associated with aspects of cognitive skills for the use of e-LMS among the students of the Faculty of Education at the University of Mu'tah, Jordan for the post- test ".

To validate the hypothesis, the mean and standard deviations were calculated and Paired Samples t-test was used to identify the differences between the mean scores of the experimental group in the pre and post-application, as shown in the following table:

Table 2. Results of test of interrelated samples to identify the significance of the differences between the average scores of the research sample members in the pre and post-application of the achievement test with a statement of the effect size.

\begin{tabular}{|c|c|c|c|c|c|c|c|c|}
\hline Test & Means & $\begin{array}{c}\text { Standard } \\
\text { deviation }\end{array}$ & $\mathrm{N}$ & $\mathrm{t}$ Test & Df & Sig. & $\eta^{2}$ & effect \\
\hline Pre test & 23.133 & 3.998 & 30 & 42.741 & 29 & 0.000 & 0.98 & $\begin{array}{c}\text { High } \\
\text { effect }\end{array}$ \\
\hline Post test & 63.133 & 4.776 & 30 & &
\end{tabular}


The results of the previous table indicate that there are statistically significant differences (0.000) among the average scores of the research sample in the pre and post-application to the achievement test related to the cognitive aspects of the skills of using the e-LMS Moodle for students of the Faculty of Education at the University of Mu'tah, Jordan. The results were for the post-test. The highest means was 63.133), The $\eta^{2}(0.98)$ and the magnitude of the activity were found to be large. This means that the volume of the activity is large and positive.

Table 3. The average scores of the students in the achievement test and the average gain rate for the McGuigan's experimental group

\begin{tabular}{|c|c|c|c|c|}
\hline $\mathrm{N}$ & Mean Pre test & Mean Post test & MC Gugians Ratio & Sig. \\
\hline 30 & 23.133 & 63.133 & 0.77 & accepable \\
\hline
\end{tabular}

Table 3 shows that the effectiveness of the virtual environment based on the combination of active learning and Interactive Google applications was acceptable according to the rate set by to McGuigan's Effectiveness Ratio that is (0.6) to be effective.

The researcher attributed the superiority of the experimental group's students in the post-application of the achievement test to the great impact of employing the virtual environment based on the combination of active learning and Interactive Google applications in developing the skills of using the Moodle e-LMS. This environment, which is based on employing Electronic Collaborative Learning Strategy and Google Interactive Applications, increases learner motivation for learning, achieves learner interaction with each other, and enables interaction with different elements of the environment, for example, the ability to interact with content through it or with the teacher. In addition, the multimedia environment leads to increase the attention of learners and the thrill of learning within themselves and this is agreed upon by the studies of (Darbawi, 2017; AlToni, 2016; Thornton,2016; Chail,2011) which emphasize the effectiveness of Google's Interactive applications in the development of skills and the need to employ them in the educational process. The study (Cahill, 2011) emphasized the need to employ and integrate Interactive Google applications with educational strategies that help collaborative and participatory work through groups. Khalil's (2014) study also highlighted the effectiveness of participatory learning strategy based on Google's Interactive applications in providing students with skills.

Test the validity of the second hypothesis of the research, which states: There is a statistically significant difference at the level of function $(\alpha \geq 0.05)$ between the average scores of the sample in the observation card results associated with aspects of practical skills for the use of e-LMS with the students of the Faculty of Education for the post-test of the observation card. To validate the hypothesis, the mean and standard deviations were calculated and Paired Samples t-test was used to identify the differences between the mean scores of the experimental group in the pre and post-application as shown in the following table: 
Table 4. The results of the $t$ Test show the comparison between the pre and post observation cards averages of the performance with a statement of the effect size

\begin{tabular}{|c|c|c|c|c|c|c|c|c|}
\hline $\begin{array}{c}\text { Performance of } \\
\text { observation card }\end{array}$ & means & $\begin{array}{c}\text { Standard } \\
\text { deviation }\end{array}$ & $\mathrm{N}$ & $\mathrm{t}$ test & $\mathrm{df}$ & Sig. & $\eta^{2}$ & effect \\
\hline Pre test & 187.967 & 21.242 & 30 & \multirow{2}{*}{33.064} & 29 & 0.000 & 0.97 & $\begin{array}{c}\text { High } \\
\text { effect }\end{array}$ \\
\hline Post test & 558.933 & 64.189 & 30 & &
\end{tabular}

It is clear from the table that there is a statistically significant difference between the mean scores of the experimental group in the pre and post applications of the observation card related to the skills of using the e-LMS among the students of the Faculty of Education for the post-application. The highest means was 558.933), The $\eta^{2}(0.97)$ and the magnitude of the activity were found to be large. This means that the volume of the activity is large and positive.

Table 5. The average scores of learners in the observation card and the average gain rate of the McGuigan's experimental group

\begin{tabular}{|c|c|c|c|c|}
\hline N & Pre-test Mean & Post-test Mean & MC Gugians Ratio & Sig. \\
\hline 30 & 187.967 & 558.933 & 0.76 & acceptable \\
\hline
\end{tabular}

Table 5 shows that the effectiveness of the virtual environment based on the combination of active learning and Interactive Google applications was acceptable according to McGuigan's Effectiveness Ratio which should be at least (0.6) ratio to be acceptable.

The development of the performance aspects of e-LMS Moodle skills by the students of the College of Education in the current research can be interpreted to the use of video clips in presenting the skills of dealing with the e-LMS through a series of organized and sequential steps accompanied by voice commentary explaining the skill. These allow the students to have the opportunity to acquire the skills effectively. It is important to mention that the practical application by the students in the performance of skills, the follow-up during their implementation of these skills and providing them with feedback contributed significantly to the acquisition of skills to use the e-LMS. In addition, the use of media and educational stimuli of texts, images and video clips that demonstrate the performance of skills Interactive ly have led to the acquisition of these skills. The use of educational activities within educational modules in the virtual environment, and providing educational resources that serve the implementation of activities and freedom of choice by the student. The presence of interaction, discussions, comments and participations that occur between members of the group within the forum contributed significantly to the acquisition of these skills. What's more to the feedback and evaluations obtained by the group from other groups contributed to the improvement of performance.

This is what is agreed with the study of the effectiveness of employing Google Interactive Applications in skills development, and recommended that they be used in the educational process (Darbawi, 2017; Al-Tony, 2016; Thoronton, 2016; Peterson, 2013). While Cahill 
(2011) stressed on the need to employ Google Interactive Applications and integrate them with educational strategies, which support collaborative and Interactive learning through groups and this is consistent with the study of the current research.

\section{Conclusions and Recommendations}

In light of the current research results, the researcher has proved the effectiveness of the virtual environment based on the integration of Electronic Collaborative Learning strategy as an active learning strategy with Interactive Google applications, which had a significant impact on the students' ability to use the e-learning management system and cooperate in the virtual environment synchronously or asynchronously, and the use of different educational media from text, audio, image and video, and access the educational content of educational modules without time or space limits, leading to learn better and more easily. So the researcher suggests some related topics, as follows: First, The impact of using Google Interactive Applications on developing instructional design skills and producing e-courses. The second is designing a virtual environment based on the combination of active learning and Interactive Google applications in developing e-learning management skills. The third is Designing a virtual environment based on an Electronic Collaborative Learning strategy in developing the students' achievement.The fourth is effectiveness of active learning based on Interactive Google applications in developing the use of Open Source Learning Management System.

The current research leads to the following recommendations in the light of the research objectives and its importance: First, to employ virtual environments based on the combination of active learning and Interactive Google applications in teaching some undergraduate courses. Second , to develop teaching methods and integrate them with Google Interactive Applications , and expand the use of Electronic Collaborative Learning strategy as one of the strategies of active learning within virtual environments. Third, the researcher recommends utilizing Google Interactive Applications in the development of many of the skills of students of the Faculty of Education, because of the great effectiveness achieved by the development of the cognitive and performance aspects of the current research skills. Fourth, to holding training programs for learners in different stages of the university about how to employ Google applications Interactive within the virtual environments according to programs prepared in advance in education and training as one of the important tools that help to learn effectively. Fifth, the researcher emphasizes the need to take advantage of the services offered by Google Interactive Applications and take advantage of their characteristics in the educational process. Finally, the researcher focuses on the need to work on preparing a new generation capable of using modern technology and employ Google Interactive Applications to get knowledge, acquire skills, and exchange experiences among learners.

\section{References}

Abdulaziz, N. M (2015). Designing a virtual environment based on participatory media for the development of self-managed e-learning and e-learning skills for high school students. Unpublished $\mathrm{PhD}$ thesis, Teachers College. Mansoura University. 
Akl, M ; Khamis, M. A \& Abu Shuqair, M (2012). Develop the adaptive performance of the Moodle program at the Islamic University of Gaza. Islamic University Journal, Volume 17. Issue 2. Pages (123-150).

AL Hussein, A. M (2014). The impact of the development of virtual learning environments in light of their design criteria in providing students with instructional design skills for e-courses. Unpublished MA thesis. Quality Teachers College. Ain-Shams University.

AL Khalifa, H.S (2009). Comparison of codes and system bridges for e-learning management. First International Conference on e-learning and Distance Learning. Riyadh: King Saud University.

Al-Tony, M. A (2016). Google Apps and its relationship to the skills of knowledge management and self-efficacy among students of educational technology. Unpublished PhD thesis. Quality Teachers College. Minia University.

Britain, S. (2004). A review of learning design: concept, specifications and tools. A report for the JISC E-learning Pedagogy Programme, 2006.

Cahill, J. L. (2011). The collaborative benefits of Google Apps Education Edition in higher education. North central University. Retrieved November 2011 from ProQuest Dissertations database. (UMI No. 3493233)

Chang, Y. H., Chen, Y. Y., Chen, N. S., Lu, Y. T., \& Fang, R. J. (2016). Yet another Adaptive Learning Management System Based on Felder and Silverman's learning styles and Mashup. Eurasia Journal of Mathematics, Science \& Technology Education, 12(5),1273-1285.

Darbawi, A.M (2017). Effectiveness of Google Interactive Application databases in developing educational page deployment skills for education technology professionals. Unpublished MA thesis. Teachers College, Mansoura University.

Ebadi, A.H (2014). Effectiveness of an e-learning environment in the development of some digital video editing skills among students of the Education Technology Division. Unpublished MA thesis, Institute of Educational Studies, Cairo University.

Farghali, Mohamed (2011). The effectiveness of an electronic course in sociology based on participatory learning in developing the ability of collective thinking and motivation for achievement among high school students. Unpublished $\mathrm{PhD}$ thesis, Faculty of Specific Education, Ain Shams University.

Ferreira, J. M. M. (2014, February). Flipped classrooms: From concept to reality using Google Apps. In Remote Engineering and Virtual Instrumentation (REV), 2014 11th International Conference on (pp. 204-208). IEEE.

Graf, S. (2007). Adaptivity in learning management systems focussing on learning styles (Doctoral dissertation, Vienna University of Technology).

Hernández, N., González, M., \& Muñoz, P. (2014). Planning collaborative learning in virtual environments. Comunicar, 21(42), 25-32.

Holmes, M. R., Tracy, E. M., Painter, L. L., Oestreich, T., \& Park, H. (2015). Moving from flipcharts to the flipped classroom: using technology driven teaching methods to 
promote active learning in foundation and advanced masters social work courses. Clinical social work journal, 43(2), 215-224.

Ismail, A. M (2009). E-learning from the application to professionalism and quality. Cairo: The World of Books.

Khalil, S. S (2014). Participatory learning based on Google's educational applications and its relationship to providing cloud computing and knowledge management skills to postgraduates. Second International Conference on e-Learning. Entitled "Participatory learning in the network society". Cairo 24-26 June. Egyptian e - Learning Association.

Kim, M. H. (2013). Working collaboratively in virtual learning environments: Using Second Life with Korean high school students in history class (Doctoral dissertation, Teachers College, Columbia University). Retrieved. From:

ktoridou, D., \& Eteokleous, N. (2013, March). Interdisciplinary Web-based learning practices in higher education. In Global Engineering Education Conference (EDUCON), 2013 IEEE (pp. 536-539). IEEE

Lynch, M. M. (2002). The online educator: A guide to creating the virtual classroom. Routledge.

Marco, F. A., Penichet, V. M. R., \& Gallud, J. A. (2013). Collaborative e-learning through Drag \& Share in Synchronous Shared Workspaces. J. UCS, 19(7), 894-911.

Nordin, N., Sham, I. B. R. A. H. I. M., Hamzah, M. I. M., Embi, M. A., \& Rosseni, D. I. N. (2012). Leveraging open source software in the education management and leadership training. TOJET: The Turkish Online Journal of Educational Technology, 11(3).

Pappas, C. (2014). 7 Tips To Use Google Sites In eLearning. Retrieved. From https://elearningindustry.com/7-tips-use-google-sites-in-elearning

Parker, M. A., \& Martin, F. (2010). Using virtual classrooms: Student perceptions of features and characteristics in an online and blended course. Journal of Online Learning and Teaching, 6(1), 135.

Rossiou, E., Paparrizos, C., \& Papadakis, S. (2009). Using LAMS to facilitate an effective synchronous virtual classroom in the teaching of algorithms to undergraduate students. In European LAMS \& Learing Design Conference.

Sarrab, M., \& Rehman, O. M. H. (2014). Empirical study of open source software selection for adoption, based on software quality characteristics. Advances in Engineering Software, 69, 1-11.

Thornton, C. (2016). Teaching Elementary School Teachers to Integrate Twenty-First Century Teaching Strategies Using Google Apps For Education. Retrieved from: https://scholarspace.manoa.hawaii.edu/handle/10125/40182

Wright, V. H., Burnham, J. J., \& Hooper, L. M. (2012). Faculty collaboration: How a wiki enhanced communication, organization, accessibility, and management of writing a book. Journal of Interactive Online Learning, 11(1), 43-46.

Zhou, Y., Wu, X., \& Zhan, H. (2014, January). Research on blended learning mode based on Moodle platform. In Proceedings of the 9th International Symposium on Linear Drives for Industry Applications, Volume 1 (pp. 279-286). Springer Berlin Heidelberg. 


\section{Appendices}

The achievement test that deals with the cognitive aspect of the skills of using the e-learning management system.

\section{Objective of the Test:}

The objective of this test is to measure the cognitive aspects associated with using the e-learning management skills by the students of the Faculty of Education.

\section{Building Test:}

The test is divided into two parts:

The first section consists of multiple choice questions (37). Each item includes the question head and the reference in numbers $(1,2,3$, $4, \ldots$.$) and four verbal alternatives to answer the question. (A, B, C, D)$ with one correct alternative.

Section 2: represents the right and wrong questions and the number of (38) questions, while the questions of right and wrong include two alternatives: (True / False), one alternative represents the True answer.

\section{Instructions for answering the Test:}

\section{Dear Student:}

-Read test questions carefully before answering them.

-Do not leave any questions without answering.

-The maximum final score of the test (75) by one degree per individual.

-Choose the answer you think is appropriate for each question.

-After completing all the test questions, click on the key on the delivery key for the final delivery of the test answers. 


\begin{tabular}{|c|c|c|c|}
\hline $\mathbf{N}$ & $\begin{array}{c}\text { Educational } \\
\text { Goal }\end{array}$ & \multicolumn{2}{|c|}{ Test Questions } \\
\hline \multicolumn{4}{|c|}{ Section One: Multiple Choice Questions. } \\
\hline 1 & $\begin{array}{l}\text { The student } \\
\text { interprets the } \\
\text { concept of } \\
\text { Moodle. }\end{array}$ & \multicolumn{2}{|c|}{$\begin{array}{l}\text { Moodle term for: } \\
\text { a.Modular Oriented Object Dynamic Learning Entertainment } \\
\text { b.Model Object Oriented Design Learning } \\
\text { c.Modular Object Oriented Dynamic Learning Environment } \\
\text { d. Model Oriented Object Design Learning Environment }\end{array}$} \\
\hline 2 & $\begin{array}{l}\text { The student } \\
\text { interprets the } \\
\text { concept of } \\
\text { Moodle. }\end{array}$ & \multicolumn{2}{|l|}{$\begin{array}{l}\text { The Modell system is one of the following: } \\
\text { A) Learning Content Management (LCMS( } \\
\text { B) CMS course management. } \\
\text { C) LMS learning management. } \\
\text { D) All of the above is true. }\end{array}$} \\
\hline 3 & $\begin{array}{l}\text { The student } \\
\text { mentions the } \\
\text { operation steps } \\
\text { of the Moodle } \\
\text { system. }\end{array}$ & \multicolumn{2}{|l|}{$\begin{array}{l}\text { You can log in to the modal system by: } \\
\text { A) Log in } \\
\text { B) Log out. } \\
\text { C) Exit. } \\
\text { D) Quit }\end{array}$} \\
\hline 4 & $\begin{array}{l}\text { Students are } \\
\text { mention of the } \\
\text { Moodle course } \\
\text { components }\end{array}$ & \multicolumn{2}{|c|}{$\begin{array}{l}\text { None of the following is not a Moodle course component: } \\
\text { A) Blocks. } \\
\text { B) Navigation Bar. } \\
\text { C) Edit Editing On / Off. } \\
\text { D) MS Exchange e-mail program. }\end{array}$} \\
\hline 5 & $\begin{array}{l}\text { The student } \\
\text { distinguishes } \\
\text { between the } \\
\text { components of } \\
\text { Moodle } \\
\text { courses. }\end{array}$ & \multicolumn{2}{|c|}{$\begin{array}{l}\text { Which of the following illustrates Moodle Course modules? } \\
\text { A) Blocks. } \\
\text { B) Edit / Close / Turn Editing On. } \\
\text { C) Navigation Bar. } \\
\text { D) Resources and activities. }\end{array}$} \\
\hline 6 & $\begin{array}{l}\text { The student } \\
\text { distinguishes } \\
\text { between the } \\
\text { components of } \\
\text { Moodle } \\
\text { courses. }\end{array}$ & $\begin{array}{l}\text { The number (1) in the corresponding screen } \\
\text { indicates: } \\
\text { A) User Name. } \\
\text { B) Password. } \\
\text { C) Signing out. } \\
\text { D) Internet Explorer. }\end{array}$ & 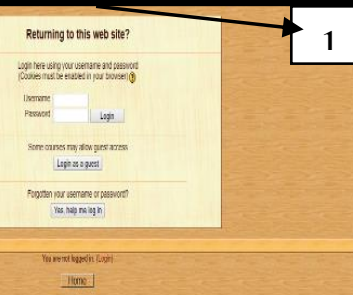 \\
\hline 7 & $\begin{array}{l}\text { The student } \\
\text { distinguishes } \\
\text { between the } \\
\text { components of } \\
\text { Moodle } \\
\text { courses. }\end{array}$ & \multicolumn{2}{|c|}{$\begin{array}{l}\text { Which of the following buttons in the navigation bar is used to return to the home } \\
\text { page of the MODEL environment? } \\
\text { A) Dictionary Glossary. } \\
\text { B) Moodle. } \\
\text { C) Navigation Bar } \\
\text { D) Edit Editing. }\end{array}$} \\
\hline
\end{tabular}




\begin{tabular}{|c|c|c|c|}
\hline $\mathbf{N}$ & $\begin{array}{c}\text { Educational } \\
\text { Goal }\end{array}$ & \multicolumn{2}{|c|}{ Test Questions } \\
\hline 8 & $\begin{array}{l}\text { The student } \\
\text { mentions steps } \\
\text { to change the } \\
\text { Moodle } \\
\text { interface. }\end{array}$ & \multicolumn{2}{|c|}{$\begin{array}{l}\text { The interface of the Moodle site is changed by: } \\
\text { A) Show Appearance of Site Administration Block. } \\
\text { B) Users of Site Administration Site Administration Block. } \\
\text { C) Themes templates from the Site Administration cluster. } \\
\text { D) All of the above. }\end{array}$} \\
\hline 9 & $\begin{array}{l}\text { The student } \\
\text { mentions the } \\
\text { steps of adding } \\
\text { a new user to } \\
\text { the modal } \\
\text { system site }\end{array}$ & \multicolumn{2}{|c|}{$\begin{array}{l}\text { Which of the following procedures do we use to add a new user to the Modell } \\
\text { system? } \\
\text { A) Add a new user- Account - Users. } \\
\text { B) Browse users list. - Account - Users. } \\
\text { C) Add new users - Users - Account. } \\
\text { D) Users - Account - Add New Users. }\end{array}$} \\
\hline 10 & $\begin{array}{l}\text { The student } \\
\text { adjusts the } \\
\text { location } \\
\text { settings using } \\
\text { the page } \\
\text { settings } \\
\text { command. }\end{array}$ & \multicolumn{2}{|l|}{$\begin{array}{l}\text { The number (1) on the corresponding } \\
\text { screen indicates: } \\
\text { A) A short name for the site. } \\
\text { B) Full name of the site } \\
\text { C) A descriptive sentence appears on the } \\
\text { home page. } \\
\text { D) Background control. }\end{array}$} \\
\hline 11 & $\begin{array}{c}\text { The student } \\
\text { mentions the } \\
\text { steps to edit the } \\
\text { CV file. }\end{array}$ & \multicolumn{2}{|c|}{$\begin{array}{l}\text { To make changes to personal data in a student's CV file, use the command: } \\
\text { A) Edit the Curriculum vitae Edit Profile. } \\
\text { B) updating the CV Update Profile. } \\
\text { C) Restore. } \\
\text { D) Upload the file upload a file. }\end{array}$} \\
\hline 12 & $\begin{array}{l}\text { The student } \\
\text { adds a new } \\
\text { course on the } \\
\text { site. }\end{array}$ & $\begin{array}{l}\text { Figure (1) shows the corresponding screen: } \\
\text { A) Full name of the course. } \\
\text { B) A short name for the course. } \\
\text { C) A brief description of the course. } \\
\text { D) To divide the course into weeks. }\end{array}$ & 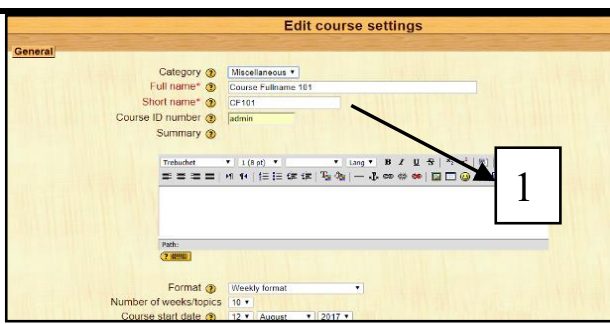 \\
\hline 13 & $\begin{array}{l}\text { The student } \\
\text { creates a } \\
\text { backup of a } \\
\text { course. }\end{array}$ & \multicolumn{2}{|c|}{$\begin{array}{l}\text { To create a backup of the scheduled hard drive, use the command: } \\
\text { A) Restore from the Site Administration cluster. } \\
\text { B) a backup copy of the Site Administration block. } \\
\text { C) Receiving from the Site Administration cluster. } \\
\text { D) restore the block of the addition of a course. }\end{array}$} \\
\hline 14 & $\begin{array}{c}\text { The student } \\
\text { will review a } \\
\text { set of files in } \\
\text { support of the } \\
\text { course. }\end{array}$ & \multicolumn{2}{|c|}{$\begin{array}{l}\text { To download a file from the supporting files for a course from a folder we choose: } \\
\text { A) Create a Make A Folder. } \\
\text { B) Browse the file Browse a file. } \\
\text { C) Upload a file. } \\
\text { D) All of the above. }\end{array}$} \\
\hline
\end{tabular}




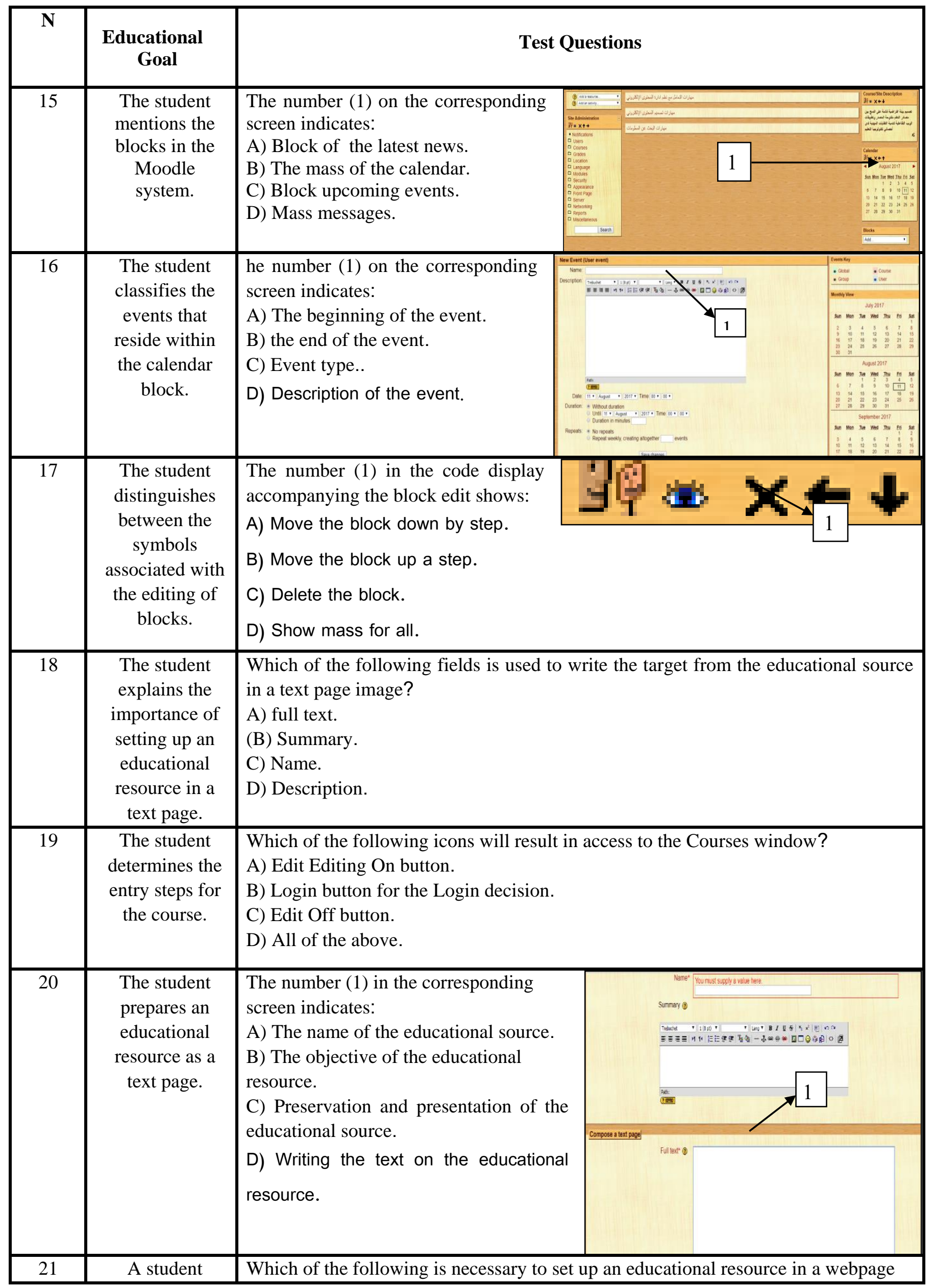




\begin{tabular}{|c|c|c|}
\hline $\mathbf{N}$ & $\begin{array}{c}\text { Educational } \\
\text { Goal }\end{array}$ & Test Questions \\
\hline & $\begin{array}{l}\text { prepares } \\
\text { educational } \\
\text { resource in a } \\
\text { webpage } \\
\text { image. }\end{array}$ & $\begin{array}{l}\text { image? } \\
\text { A) Format text with word processor tools. } \\
\text { B) Insert an image or symbol. } \\
\text { C) Insert a table. } \\
\text { D) All of the above is true. }\end{array}$ \\
\hline 22 & $\begin{array}{l}\text { The student } \\
\text { mentions the } \\
\text { symbols that } \\
\text { work on } \\
\text { organizing } \\
\text { each section of } \\
\text { subjects. }\end{array}$ & $\begin{array}{l}\text { The following icons work on organizing each section of topics except: } \\
\qquad \begin{array}{lll}\text { (B) } & \text { (D) }\end{array}\end{array}$ \\
\hline 23 & $\begin{array}{l}\text { The student } \\
\text { distinguishes } \\
\text { between the } \\
\text { symbols that } \\
\text { organize each } \\
\text { section of the } \\
\text { subjects. }\end{array}$ & $\begin{array}{l}\text { The number (1) in the corresponding screen indicates: } \\
\text { A) Show a section without the rest of the sections. } \\
\text { B) Hide a section . } \\
\text { C) Show all hidden sections } \\
\text { D) All of the above is true. }\end{array}$ \\
\hline 24 & $\begin{array}{c}\text { The student } \\
\text { demonstrates } \\
\text { the significance } \\
\text { of the } \\
\text { description } \\
\text { field when } \\
\text { preparing the } \\
\text { task. }\end{array}$ & $\begin{array}{l}\text { Which of the following fields are written instructions that explain how the student } \\
\text { answered questions in a task of the type of direct text Online Text? } \\
\text { A) full text. } \\
\text { B) Name. } \\
\text { C) Summary. } \\
\text { D) Description. }\end{array}$ \\
\hline 25 & $\begin{array}{c}\text { The student } \\
\text { creates an } \\
\text { offline activity. }\end{array}$ & $\begin{array}{l}\text { Which of the following commands is used to deliver tasks to the teacher } \\
\text { simultaneously? } \\
\text { A) chat conversation. } \\
\text { B) a referendum of choice. } \\
\text { C) offline activity. } \\
\text { D) Quiz test. }\end{array}$ \\
\hline 26 & $\begin{array}{l}\text { Students } \\
\text { demonstrate } \\
\text { the concept of } \\
\text { a glossary or } \\
\text { glossary within } \\
\text { the site. }\end{array}$ & $\begin{array}{l}\text { The term, which expresses the establishment of a database related to the terms of the } \\
\text { so-called decision: } \\
\text { A) chat conversation. } \\
\text { B) A referendum of choice. } \\
\text { C) offline activity. } \\
\text { D) Dictionary Glossary. }\end{array}$ \\
\hline
\end{tabular}




\begin{tabular}{|c|c|c|c|}
\hline $\mathbf{N}$ & $\begin{array}{c}\text { Educational } \\
\text { Goal }\end{array}$ & \multicolumn{2}{|c|}{ Test Questions } \\
\hline 27 & $\begin{array}{l}\text { The student } \\
\text { mentions steps } \\
\text { to create the } \\
\text { dictionary } \\
\text { within the site. }\end{array}$ & $\begin{array}{l}\text { The number (1) in the corresponding screen } \\
\text { indicates: } \\
\text { A) The number of terms presented per page. } \\
\text { B) The possibility of printing or preventing the } \\
\text { term. } \\
\text { C) Save and display the dictionary. } \\
\text { D) Automatically link dictionary terms. }\end{array}$ & 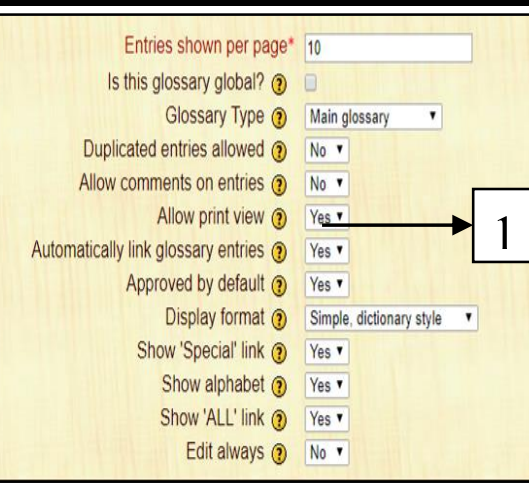 \\
\hline 28 & $\begin{array}{l}\text { The student } \\
\text { distinguishes } \\
\text { between } \\
\text { symbols of } \\
\text { educational } \\
\text { sources and } \\
\text { activities. }\end{array}$ & $\begin{array}{l}\text { The number (1) in the corresponding screen ind } \\
\text { A) Update. } \\
\text { B) Move Right to Move Right. } \\
\text { C) Hide. } \\
\text { D) Show. }\end{array}$ & tes: \\
\hline 29 & $\begin{array}{l}\text { The student } \\
\text { shows the } \\
\text { source or } \\
\text { educational } \\
\text { activity for } \\
\text { everyone } \\
\text { through the } \\
\text { Show icon. }\end{array}$ & $\begin{array}{l}\text { Which of the following symbols is used to sh } \\
\text { added to the site? }\end{array}$ & $\begin{array}{l}\text { the activity or educational source } \\
\qquad \begin{array}{|l|l} & \text { (द) }\end{array}\end{array}$ \\
\hline 30 & $\begin{array}{l}\text { The student } \\
\text { will modify the } \\
\text { source or } \\
\text { educational } \\
\text { activity of the } \\
\text { course through } \\
\text { the (Update). }\end{array}$ & $\begin{array}{l}\text { Which of the following symbols is used to mo } \\
\text { added to the site? } \\
\qquad \begin{array}{lll}\text { (B) } & \text { (D) }\end{array}\end{array}$ & 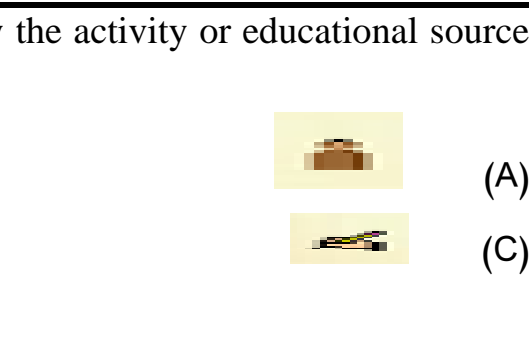 \\
\hline 31 & $\begin{array}{l}\text { The student } \\
\text { demonstrates } \\
\text { the significance } \\
\text { of each of the } \\
\text { following } \\
\text { fields: Open } \\
\text { field test, field } \\
\text { close test. }\end{array}$ & $\begin{array}{l}\text { Which of the following fields is used to determ } \\
\text { A) Open the Quiz. } \\
\text { B) Close the Quiz. } \\
\text { C) Exit the Quiz. } \\
\text { D) Quiz Name. }\end{array}$ & the test opening date for students? \\
\hline
\end{tabular}




\begin{tabular}{|c|c|c|c|}
\hline $\mathbf{N}$ & Educational & \multicolumn{2}{|c|}{ Test Questions } \\
\hline 32 & $\begin{array}{l}\text { The student } \\
\text { determines the } \\
\text { steps to add } \\
\text { Quiz to the } \\
\text { course. }\end{array}$ & $\begin{array}{l}\text { The number (1) in the corresponding screen } \\
\text { indicates: } \\
\text { A) Provide the test without a window. } \\
\text { B) Objective of the test. } \\
\text { C) The closing time of the test. } \\
\text { D) Time spent on first and second attempt. }\end{array}$ & 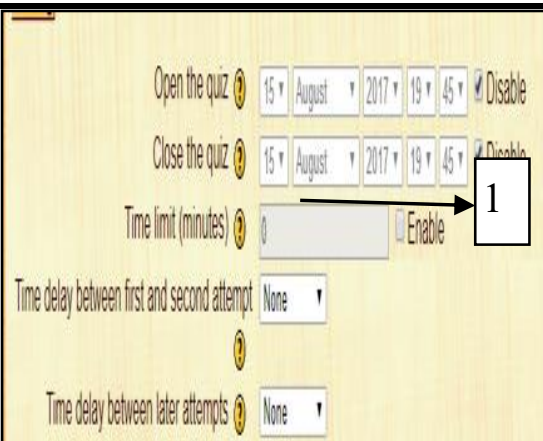 \\
\hline 33 & $\begin{array}{l}\text { The student } \\
\text { determines the } \\
\text { steps to add } \\
\text { Quiz to the } \\
\text { course. }\end{array}$ & $\begin{array}{l}\text { The number (1) in the corresponding screen } \\
\text { indicates: } \\
\text { A) Provide the test without a window. } \\
\text { B) Objective of the test. } \\
\text { C) The closing time of the test. } \\
\text { D) Time spent on first and second attempt. }\end{array}$ & 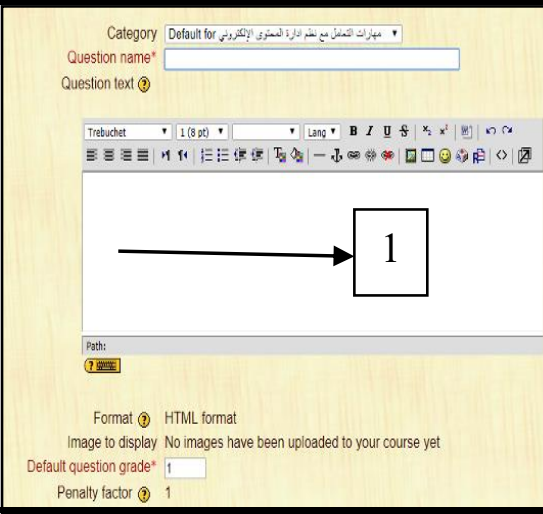 \\
\hline 34 & $\begin{array}{l}\text { The student } \\
\text { creates a valid } \\
\text { or false test } \\
\text { (True / False) } \\
\text { for the question } \\
\text { bank. }\end{array}$ & $\begin{array}{l}\text { The number (1) in the corresponding screen } \\
\text { indicates: } \\
\text { A) The text of the question. } \\
\text { B) Feedback for the True answer. } \\
\text { C) Determine the True answer. } \\
\text { D) Feedback for the wrong answer. }\end{array}$ & 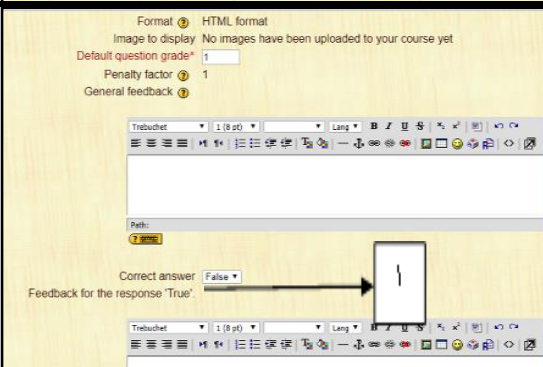 \\
\hline 35 & $\begin{array}{c}\text { The student } \\
\text { creates a valid } \\
\text { or false test } \\
\text { (True / False) } \\
\text { for the question } \\
\text { bank. }\end{array}$ & $\begin{array}{l}\text { he number (1) in the corresponding screen } \\
\text { indicates: } \\
\text { A) The text of the question. } \\
\text { B) Feedback for the wrong answer. } \\
\text { C) Determine the True answer. } \\
\text { D) Degree of question. }\end{array}$ & 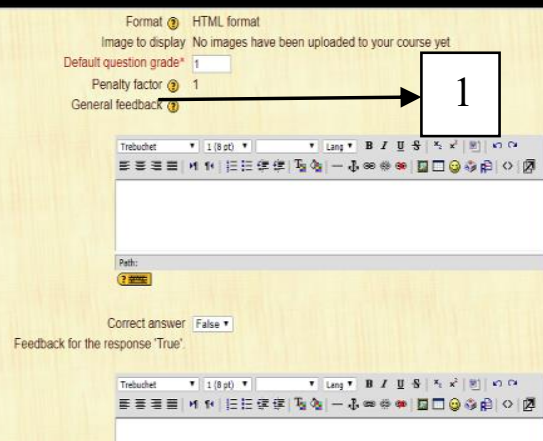 \\
\hline
\end{tabular}




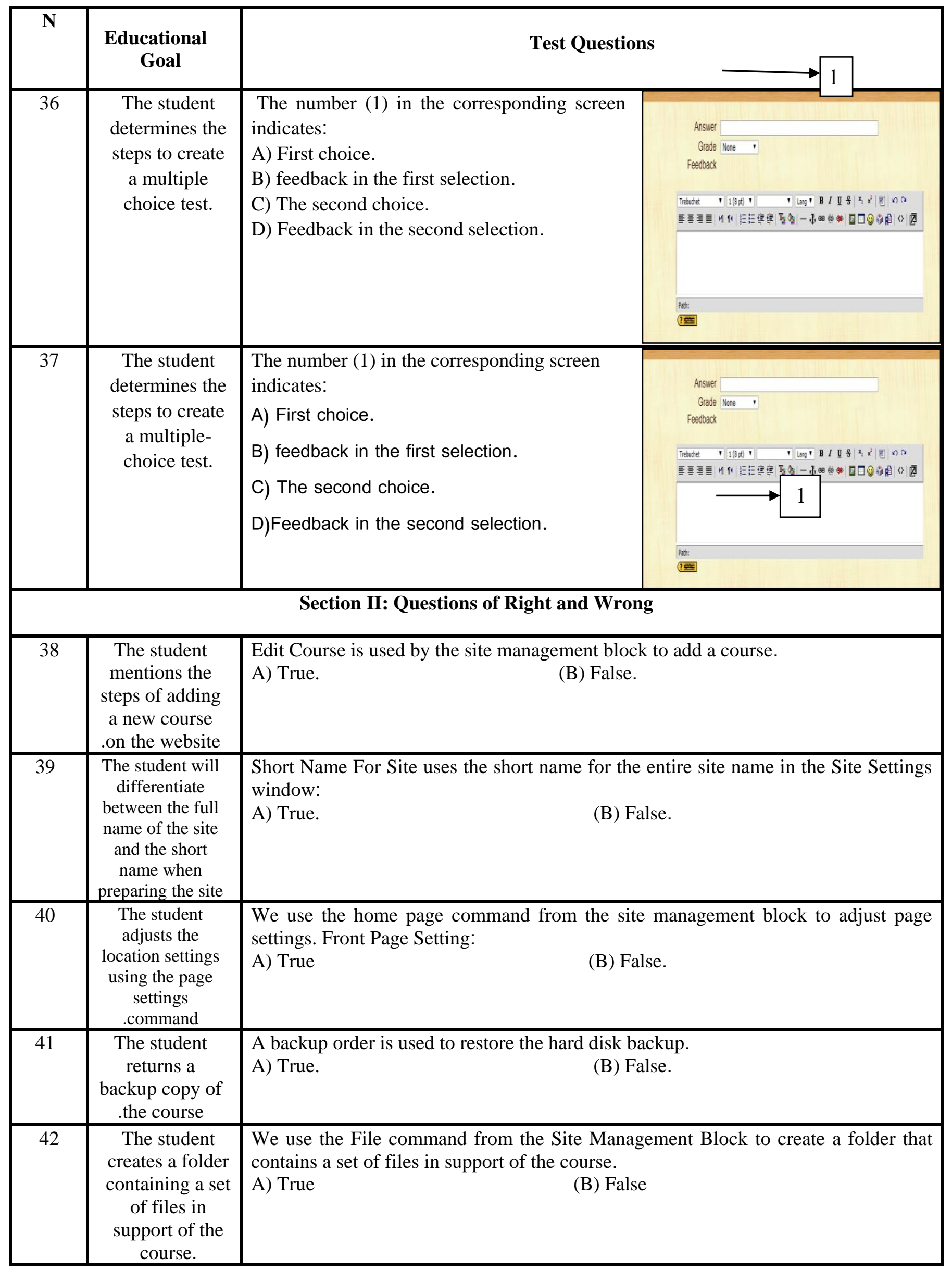




\begin{tabular}{|c|c|c|}
\hline $\mathbf{N}$ & $\begin{array}{l}\text { Educational } \\
\text { Goal }\end{array}$ & Test Questions \\
\hline 43 & $\begin{array}{l}\text { Students are } \\
\text { mention of the } \\
\text { Moodle course } \\
\text { components. }\end{array}$ & $\begin{array}{l}\text { The navigation bar is a component of the Modell course. It is necessary to appear on } \\
\text { the home page. } \\
\begin{array}{ll}\text { A) True. } & \text { (B) False. }\end{array}\end{array}$ \\
\hline 44 & $\begin{array}{l}\text { The student } \\
\text { creates a folder } \\
\text { containing a set } \\
\text { of files in } \\
\text { support of the } \\
\text { course. }\end{array}$ & $\begin{array}{l}\text { To create a folder that contains a set of files in support of the course, click on the } \\
\text { Make A Folder icon. } \\
\begin{array}{ll}\text { A) True } & \text { (B) False }\end{array}\end{array}$ \\
\hline 45 & $\begin{array}{l}\text { The student } \\
\text { mentions the } \\
\text { steps of } \\
\text { reviewing the } \\
\text { participants. }\end{array}$ & $\begin{array}{l}\text { We use the Add New Users command to browse the site's subscribers. } \\
\begin{array}{ll}\text { A) True. } & \text { (B) False. }\end{array}\end{array}$ \\
\hline 46 & $\begin{array}{l}\text { The student } \\
\text { mentions the } \\
\text { importance of } \\
\text { the latest news } \\
\text { block. }\end{array}$ & $\begin{array}{l}\text { Show latest topics added to the forum in the block Latest News Latest New: } \\
\begin{array}{ll}\text { A) True. } & \text { (B) False. }\end{array}\end{array}$ \\
\hline 47 & $\begin{array}{l}\text { The student } \\
\text { adds new notes } \\
\text { and news } \\
\text { through the } \\
\text { latest news } \\
\text { block. }\end{array}$ & $\begin{array}{l}\text { New news is added to the Moodle system by clicking on the New Theme button of } \\
\text { the upcoming event block: } \\
\begin{array}{ll}\text { A) True. } & \text { (B) False. }\end{array}\end{array}$ \\
\hline 48 & $\begin{array}{l}\text { The student } \\
\text { classifies the } \\
\text { upcoming } \\
\text { events of the } \\
\text { courses } \\
\text { according to a } \\
\text { timetable. }\end{array}$ & $\begin{array}{l}\text { he block of upcoming events allows for a schedule of upcoming events related to } \\
\text { courses. } \\
\begin{array}{ll}\text { A) True. } & \text { (B) False. }\end{array}\end{array}$ \\
\hline 49 & $\begin{array}{c}\text { The student can } \\
\text { send and } \\
\text { receive } \\
\text { messages } \\
\text { within the site. }\end{array}$ & $\begin{array}{l}\text { he Save Message button is pressed after you finish writing the message to be sent to } \\
\text { someone from within the Model site. } \\
\begin{array}{ll}\text { A) True. } & \text { (B) False. }\end{array}\end{array}$ \\
\hline 50 & $\begin{array}{c}\text { The student } \\
\text { makes } \\
\text { amendments and } \\
\text { additions to the } \\
\text { block of modern } \\
\text { activities in a } \\
\text { concise or } \\
\text { detailed manner. }\end{array}$ & $\begin{array}{l}\text { Modifications and additions are reviewed in a concise or detailed manner through the } \\
\text { block of modern activities. } \\
\begin{array}{ll}\text { A) True. } & \text { (B) False. }\end{array}\end{array}$ \\
\hline 51 & $\begin{array}{l}\text { The student can } \\
\text { search for a } \\
\text { course within } \\
\text { the site. }\end{array}$ & $\begin{array}{l}\text { For a specific on-site course, click the All Courses button } \\
\begin{array}{ll}\text { A) True. } & \text { (B) False. }\end{array}\end{array}$ \\
\hline
\end{tabular}




\begin{tabular}{|c|c|c|}
\hline $\mathbf{N}$ & $\begin{array}{c}\text { Educational } \\
\text { Goal }\end{array}$ & Test Questions \\
\hline 52 & $\begin{array}{c}\text { A student can } \\
\text { describe a } \\
\text { course that has } \\
\text { been added } \\
\text { with one or } \\
\text { more } \\
\text { information } \\
\text { paragraphs. } \\
\end{array}$ & $\begin{array}{l}\text { A summary of the course is shown in the Course / Site Description block. } \\
\begin{array}{ll}\text { A) True. } & \text { (B) False. }\end{array}\end{array}$ \\
\hline 53 & $\begin{array}{l}\text { The student can } \\
\text { move the block } \\
\text { up by step. }\end{array}$ & $\begin{array}{l}\text { Move the block up by a step that uses the icon } \\
\begin{array}{ll}\text { A) True. } & \text { (B) False }\end{array}\end{array}$ \\
\hline 54 & $\begin{array}{l}\text { The student } \\
\text { distinguishes } \\
\text { between the } \\
\text { components of } \\
\text { the Moodle } \\
\text { course window. }\end{array}$ & $\begin{array}{l}\text { he Navigation Bar is one of the components of the Moodle Course Window. } \\
\begin{array}{ll}\text { A) True. } & \text { (B) False. }\end{array}\end{array}$ \\
\hline 55 & $\begin{array}{l}\text { The student } \\
\text { determines the } \\
\text { steps to set up } \\
\text { an educational } \\
\text { source in a } \\
\text { Web page } \\
\text { image. }\end{array}$ & $\begin{array}{l}\text { To set up an educational source in a web page image, click Add Resource. } \\
\begin{array}{ll}\text { A) True. } & \text { (B) False. }\end{array}\end{array}$ \\
\hline 56 & $\begin{array}{l}\text { The student } \\
\text { mentions the } \\
\text { steps of adding } \\
\text { an educational } \\
\text { source in a } \\
\text { collage. }\end{array}$ & $\begin{array}{l}\text { To add a tutorial source in an Insert Label you need to insert a name or a summary. } \\
\begin{array}{ll}\text { A) True. } & \text { (B) False. }\end{array}\end{array}$ \\
\hline 57 & $\begin{array}{l}\text { The student } \\
\text { mentions the } \\
\text { steps of adding } \\
\text { an educational } \\
\text { resource in the } \\
\text { form of a link to } \\
\text { a file or site. }\end{array}$ & $\begin{array}{l}\text { To add an educational source as a link to a file or website we need to write the URL } \\
\text { of the website. } \\
\begin{array}{ll}\text { A) True. } & \text { (B) False. }\end{array}\end{array}$ \\
\hline 58 & $\begin{array}{c}\text { The student } \\
\text { distinguishes the } \\
\text { educational section } \\
\text { in which the } \\
\text { educational } \\
\text { activity is located } \\
\text { without any other } \\
\text { sections. }\end{array}$ & $\begin{array}{l}\text { he code } \\
\text { activity trat uors not belong to the rest of the sections. } \\
\begin{array}{ll}\text { A) True. } & \text { (B) False. }\end{array}\end{array}$ \\
\hline 59 & $\begin{array}{l}\text { The student } \\
\text { sets specific } \\
\text { appointments } \\
\text { for the }\end{array}$ & $\begin{array}{l}\text { To set specific appointments for the conversation, a Repeated Sessions button is } \\
\text { pressed. } \\
\begin{array}{ll}\text { A) True. } & \text { (B) False. }\end{array}\end{array}$ \\
\hline
\end{tabular}




\begin{tabular}{|c|c|c|}
\hline $\mathbf{N}$ & $\begin{array}{c}\text { Educational } \\
\text { Goal }\end{array}$ & Test Questions \\
\hline & conversations. & \\
\hline 60 & $\begin{array}{c}\text { The student } \\
\text { shows steps to } \\
\text { upload a single } \\
\text { file within the } \\
\text { site. }\end{array}$ & $\begin{array}{l}\text { To upload a single file within the site Upload A Single File It is not necessary to } \\
\text { specify the time and date the task is available and closed. } \\
\begin{array}{ll}\text { A) True. } & \text { (B) False. }\end{array}\end{array}$ \\
\hline 61 & $\begin{array}{l}\text { The student can } \\
\text { upload one file } \\
\text { within the site. }\end{array}$ & $\begin{array}{l}\text { To upload a single file within the site, you must specify the degree to which the task } \\
\text { is evaluated. } \\
\begin{array}{ll}\text { A) True. } & \text { (B) False. }\end{array}\end{array}$ \\
\hline 62 & $\begin{array}{l}\text { The student } \\
\text { explains the } \\
\text { date of } \\
\text { availability and } \\
\text { closure of the } \\
\text { assignment. }\end{array}$ & $\begin{array}{l}\text { To create a task of direct text type, you must specify the time and date the task is } \\
\text { available and close from the Due Date field. } \\
\begin{array}{ll}\text { A) True } & \text { (B) False }\end{array}\end{array}$ \\
\hline 63 & $\begin{array}{l}\text { The student } \\
\text { will indicate } \\
\text { the field of the } \\
\text { re-assignment } \\
\text { assignment. }\end{array}$ & $\begin{array}{l}\text { The Resubmitting task is used to allow the student to resubmit the Trueed task or } \\
\text { tasks and to monitor their grades again. } \\
\begin{array}{ll}\text { A) True } & \text { (B) False }\end{array}\end{array}$ \\
\hline 64 & $\begin{array}{l}\text { The student } \\
\text { selects steps to } \\
\text { create a task of } \\
\text { direct text type. }\end{array}$ & $\begin{array}{l}\text { To create a task of direct text type, an Online Text command is selected from the } \\
\text { activity block. } \\
\begin{array}{ll}\text { A) True. } & \text { (B) False. }\end{array}\end{array}$ \\
\hline 65 & $\begin{array}{l}\text { The student } \\
\text { explains the } \\
\text { significance of } \\
\text { the referendum } \\
\text { concept. }\end{array}$ & $\begin{array}{l}\text { referendum is one or more questions that are directed to students to answer to see } \\
\text { what they think about a particular activity. } \\
\begin{array}{ll}\text { A) True. } & \text { (B) False. }\end{array}\end{array}$ \\
\hline 66 & $\begin{array}{l}\text { The student } \\
\text { mentions the } \\
\text { steps to create a } \\
\text { referendum } \\
\text { activity within } \\
\text { the site. }\end{array}$ & $\begin{array}{l}\text { It is necessary to specify the number of referendum options in the Limit The Number } \\
\text { Responses Allowed box when setting up a poll. } \\
\begin{array}{ll}\text { A) True. } & \text { (B) False. }\end{array}\end{array}$ \\
\hline 67 & $\begin{array}{c}\text { The student } \\
\text { demonstrates the } \\
\text { significance of } \\
\text { the text selection } \\
\text { field. }\end{array}$ & $\begin{array}{l}\text { The View property is used vertically to set the poll options horizontally. } \\
\begin{array}{ll}\text { A) True. } & \text { (B) False. }\end{array}\end{array}$ \\
\hline
\end{tabular}




\begin{tabular}{|c|c|c|}
\hline $\mathbf{N}$ & $\begin{array}{l}\text { Educational } \\
\text { Goal }\end{array}$ & Test Questions \\
\hline 68 & $\begin{array}{l}\text { The student adds } \\
\text { one of the terms } \\
\text { of his course to } \\
\text { the dictionary. }\end{array}$ & $\begin{array}{l}\text { The Add New Entry key is added to add a new term to the course through the } \\
\text { dictionary. } \\
\begin{array}{ll}\text { A) True. } & \text { (B) False. }\end{array}\end{array}$ \\
\hline 69 & $\begin{array}{l}\text { The student } \\
\text { searches for a } \\
\text { term from within } \\
\text { the language } \\
\text { dictionary. }\end{array}$ & $\begin{array}{l}\text { To search for a term within a dictionary, the term you want to search for is written in } \\
\text { the Browse field. } \\
\begin{array}{ll}\text { A) True. } & \text { (B) False. }\end{array}\end{array}$ \\
\hline 70 & $\begin{array}{l}\text { The student } \\
\text { hides the source } \\
\text { or educational } \\
\text { activity from } \\
\text { everyone by } \\
\text { hiding. }\end{array}$ & $\begin{array}{l}\text { The code } \\
\text { participants. } \\
\begin{array}{ll}\text { A) True. } & \text { (B) False. }\end{array}\end{array}$ \\
\hline 71 & $\begin{array}{l}\text { The student } \\
\text { lists the types } \\
\text { of questions in } \\
\text { the Moodle } \\
\text { system. }\end{array}$ & $\begin{array}{l}\text { The Moodle system provides a test of multiple choice type, just right and wrong } \\
\text { questions. } \\
\begin{array}{ll}\text { A) True. } & \text { (B) False. }\end{array}\end{array}$ \\
\hline 72 & $\begin{array}{l}\text { The student } \\
\text { returns a } \\
\text { question that has } \\
\text { been added to } \\
\text { the site. }\end{array}$ & $\begin{array}{l}\text { To rephrase a test vocabulary, click the Edit button from the Question Bank window. } \\
\begin{array}{ll}\text { A) True. } & \text { (B) False. }\end{array}\end{array}$ \\
\hline 73 & $\begin{array}{c}\text { The student } \\
\text { examines a } \\
\text { question that } \\
\text { has been added } \\
\text { to the site. }\end{array}$ & $\begin{array}{l}\text { To preview the question that has been added, click the Show button in the question } \\
\text { bank window. } \\
\begin{array}{ll}\text { A) True. } & \text { (B) False. }\end{array}\end{array}$ \\
\hline 74 & $\begin{array}{l}\text { The student sets } \\
\text { the test viewing } \\
\text { feature and } \\
\text { provides } \\
\text { protection and } \\
\text { safety. }\end{array}$ & $\begin{array}{l}\text { You can only set the View Test Questions feature by entering your password. } \\
\begin{array}{ll}\text { A) True. } & \text { (B) False. }\end{array}\end{array}$ \\
\hline 75 & $\begin{array}{l}\text { The student logs } \\
\text { off the site. }\end{array}$ & $\begin{array}{l}\text { You can exit the system location without clicking the Logging Out button } \\
\begin{array}{ll}\text { A) True. } & \text { (B) False. }\end{array}\end{array}$ \\
\hline
\end{tabular}


List of skills associated with the use of e-learning Management System Moodle.

\begin{tabular}{|c|c|c|}
\hline $\mathbf{N}$ & $\begin{array}{c}\text { List Skills Using Moodle } \\
\end{array}$ & Sub-skills \\
\hline \multicolumn{3}{|c|}{ Module 1: Identify and operate the Moodle environment } \\
\hline 1 & Operates the Moodle system. & 3 \\
\hline 2 & Log in to the site & 4 \\
\hline 3 & It reviews the components of Moodle system courses. & 3 \\
\hline \multicolumn{3}{|c|}{ Module 2: Dealing with some site Administration blocks options. } \\
\hline 4 & Changes the interface of the Moodle system. & 2 \\
\hline 5 & Adds a new user & 5 \\
\hline 6 & Edit the CV file & 4 \\
\hline 7 & Review Site visitors & 3 \\
\hline 8 & Adjusts page settings in the site with the Front Page Setting command & 5 \\
\hline 9 & Adds a new curriculum and divide it into topics. & 9 \\
\hline 10 & Creates a backup of a course & 6 \\
\hline 11 & Retrieves a backup of the course & 5 \\
\hline 12 & Creates a folder that contains a set of support files of the course. & 9 \\
\hline 13 & Deletes student registration. & 2 \\
\hline \multicolumn{3}{|c|}{ Module 3: dealing with some blocks in the system Moodle and its associated symbols. } \\
\hline 14 & Add news or comments registered in the blocks Latest News. & 6 \\
\hline 15 & Creates a blocksof upcoming events. & 2 \\
\hline 16 & Adds an event in the Calendar blocksthrough the Cluster list. & 8 \\
\hline 17 & Adds messages between the learners or the teacher through the site. & 6 \\
\hline 18 & Receives messages from within the site. & 2 \\
\hline 19 & $\begin{array}{l}\text { Reviews amendments and additions in a brief or detailed way from Recent Activity } \\
\text { Section. }\end{array}$ & 3 \\
\hline 20 & Follows all courses from within the site. & 2 \\
\hline 21 & Follows specific course within the site. & 3 \\
\hline 22 & A summary of the course is shown in the description section of the course. & 1 \\
\hline 23 & Handles the icons associated with editing sectionss. & 6 \\
\hline \multicolumn{3}{|c|}{ Module 4: Adding and managing educational resources in the Moodle system. } \\
\hline 24 & Recognizes the components of the course window in the Moodle system. & 5 \\
\hline 25 & Prepares educational source is a text page (Compose A Test Page). & 7 \\
\hline 26 & Adds an educational source in a Web page image (Compose A Web Page). & 11 \\
\hline 27 & Adds an educational source in an Insert Label. & 3 \\
\hline 28 & $\begin{array}{l}\text { Goes back to the Courses window on the site after finished the preparing the educational } \\
\text { resource. }\end{array}$ & 1 \\
\hline 29 & Displays a folder that is located in the Course Files as a learning source image. & 5 \\
\hline 30 & Adds an educational source as a link to a file or website (Link To a File or Web Site) & 5 \\
\hline 31 & Deals with tools that organize each section of topics. & 5 \\
\hline \multicolumn{3}{|c|}{$\begin{array}{l}\text { Module 5: Adding some educational activities to the Moodle system, and dealing with codes for } \\
\text { educational resources and activities. }\end{array}$} \\
\hline 32 & Adds a forum on the Moodle site. & 5 \\
\hline 33 & Adds a chat on the Moodle site. & 6 \\
\hline 34 & Creates a file upload task within the site (Upload A Single File). & 7 \\
\hline 35 & Adds a task of Direct Text (Online Text) type. & 7 \\
\hline 36 & Adds the questionaire activity task (Choice) within the site. & 9 \\
\hline 37 & Adds an offline activity. & 6 \\
\hline 38 & Go back to the scheduled window to see the activities have been added. & 1 \\
\hline 39 & Creates a dictionary of terms for the course within the site. & 5 \\
\hline 40 & Searches for a term from within the linguistic dictionary. & 1 \\
\hline 41 & Adds new terms in the dictionary. & 2 \\
\hline 42 & Deals with codes for educational resources and activities. & 6 \\
\hline \multicolumn{3}{|c|}{ Module 6: Adding quiz questions to Moodle and logging out. } \\
\hline 43 & Creates Quiz for the course within the site. & 10 \\
\hline 44 & Creates a True or False test. & 8 \\
\hline 45 & Creates a multiple choice test. & 7 \\
\hline 46 & Logging Out. & 2 \\
\hline
\end{tabular}


Note card of the practical performance associated with using the e-Learning

Management System (Moodle).

\begin{tabular}{|c|c|c|}
\hline $\mathbf{N}$ & $\begin{array}{c}\text { List Skills Using Moodle } \\
\end{array}$ & Sub-skills \\
\hline \multicolumn{3}{|c|}{ Module 1: Identify and operate the Moodle environment } \\
\hline 1 & Operates the Moodle system. & 3 \\
\hline 2 & Log in to the site & 4 \\
\hline 3 & It reviews the components of Moodle system courses. & 3 \\
\hline \multicolumn{3}{|c|}{ Module 2: Dealing with some site Administration blocks options. } \\
\hline 4 & Changes the interface of the Moodle system. & 2 \\
\hline 5 & Adds a new user & 5 \\
\hline 6 & Edit the CV file & 4 \\
\hline 7 & Review Site visitors & 3 \\
\hline 8 & Adjusts page settings in the site with the Front Page Setting command & 5 \\
\hline 9 & Adds a new curriculum and divide it into topics. & 9 \\
\hline 10 & Creates a backup of a course & 6 \\
\hline 11 & Retrieves a backup of the course & 5 \\
\hline 12 & Creates a folder that contains a set of support files of the course. & 9 \\
\hline 13 & Deletes student registration. & 2 \\
\hline \multicolumn{3}{|c|}{ Module 3: dealing with some blocks in the system Moodle and its associated symbols. } \\
\hline 14 & Add news or comments registered in the blocks Latest News. & 6 \\
\hline 15 & Creates a blocksof upcoming events. & 2 \\
\hline 16 & Adds an event in the Calendar blocksthrough the Cluster list. & 8 \\
\hline 17 & Adds messages between the learners or the teacher through the site. & 6 \\
\hline 18 & Receives messages from within the site. & 2 \\
\hline 19 & $\begin{array}{l}\text { Reviews amendments and additions in a brief or detailed way from Recent Activity } \\
\text { Section. }\end{array}$ & 3 \\
\hline 20 & Follows all courses from within the site. & 2 \\
\hline 21 & Follows specific course within the site. & 3 \\
\hline 22 & A summary of the course is shown in the description section of the course. & 1 \\
\hline 23 & Handles the icons associated with editing sectionss. & 6 \\
\hline \multicolumn{3}{|c|}{ Module 4: Adding and managing educational resources in the Moodle system. } \\
\hline 24 & Recognizes the components of the course window in the Moodle system. & 5 \\
\hline 25 & Prepares educational source is a text page (Compose A Test Page). & 7 \\
\hline 26 & Adds an educational source in a Web page image (Compose A Web Page). & 11 \\
\hline 27 & Adds an educational source in an Insert Label. & 3 \\
\hline 28 & $\begin{array}{l}\text { Goes back to the Courses window on the site after finished the preparing the educational } \\
\text { resource. }\end{array}$ & 1 \\
\hline 29 & Displays a folder that is located in the Course Files as a learning source image. & 5 \\
\hline 30 & Adds an educational source as a link to a file or website (Link To a File or Web Site) & 5 \\
\hline 31 & Deals with tools that organize each section of topics. & 5 \\
\hline \multicolumn{3}{|c|}{$\begin{array}{l}\text { Module 5: Adding some educational activities to the Moodle system, and dealing with codes for } \\
\text { educational resources and activities. }\end{array}$} \\
\hline 32 & Adds a forum on the Moodle site. & 5 \\
\hline 33 & Adds a chat on the Moodle site. & 6 \\
\hline 34 & Creates a file upload task within the site (Upload A Single File). & 7 \\
\hline 35 & Adds a task of Direct Text (Online Text) type. & 7 \\
\hline 36 & Adds the questionaire activity task (Choice) within the site. & 9 \\
\hline 37 & Adds an offline activity. & 6 \\
\hline 38 & Go back to the scheduled window to see the activities have been added. & 1 \\
\hline 39 & Creates a dictionary of terms for the course within the site. & 5 \\
\hline 40 & Searches for a term from within the linguistic dictionary. & 1 \\
\hline 41 & Adds new terms in the dictionary. & 2 \\
\hline 42 & Deals with codes for educational resources and activities. & 6 \\
\hline \multicolumn{3}{|c|}{ Module 6: Adding quiz questions to Moodle and logging out. } \\
\hline 43 & Creates Quiz for the course within the site. & 10 \\
\hline 44 & Creates a True or False test. & 8 \\
\hline 45 & Creates a multiple choice test. & 7 \\
\hline 46 & Logging Out. & 2 \\
\hline
\end{tabular}




\section{Students' opinion on the knowledge and skill aspects associated}

with the use of e-Learning Management System (Moodle).

\begin{tabular}{|c|l|l|l|l|}
\hline \hline N & \multicolumn{1}{|c|}{ Survey items } & The opinion & Notes \\
\cline { 5 - 5 } & & Yes & No & \\
\hline 1 & Can you handle the e-Learning Management System (Moodle)? & & & \\
\hline 2 & Can you access and operate the Model system? & & & \\
\hline 3 & Can you create an account on the Model system? & & & \\
\hline 4 & $\begin{array}{l}\text { Can you handle some of the options of e-Learning System Management } \\
\text { blocks in the Moodle environment? }\end{array}$ & & \\
\hline 5 & Can you send and receive messages in Moodle? & & & \\
\hline 6 & Can you move among the Moodle blocks? & & \\
\hline 7 & Can you upload files from your computer to the Moodle system? & & & \\
\hline 8 & Can you download files from Moodle? & & & \\
\hline 9 & $\begin{array}{l}\text { Can you deal with the symbols associated with the editing of blocks in } \\
\text { the Moodle system? }\end{array}$ & & \\
\hline 10 & $\begin{array}{l}\text { Can you add some learning resources to the e-Learning Management } \\
\text { System (Moodle)? }\end{array}$ & & & \\
\hline 11 & Can you add some learning activities to Moodle? & & & \\
\hline 12 & $\begin{array}{l}\text { Can you handle codes for resources and educational activities in the } \\
\text { Moodle system? }\end{array}$ & & & \\
\hline 13 & $\begin{array}{l}\text { Can you add multiple choice questions in the Moodle e-Learning } \\
\text { Management System? }\end{array}$ & & & \\
\hline 14 & $\begin{array}{l}\text { Can you add the true and false questions in the e-Learning Management } \\
\text { System? }\end{array}$ & & & \\
\hline 15 & Can you log out of Moodle? & & & \\
\hline 16 & Can you handle some Google Apps? & & \\
\hline 17 & $\begin{array}{l}\text { Have you ever learned to using Electronic Collaborative Learning } \\
\text { strategy? }\end{array}$ & & & \\
\hline \hline
\end{tabular}

\section{Copyright Disclaimer}

Copyright reserved by the author(s).

This article is an open-access article distributed under the terms and conditions of the

Creative Commons Attribution license (http://creativecommons.org/licenses/by/3.0/). 